Educational Research for Social Change (ERSC)

Volume 10 No. 2 September 2021

pp. 33-46

ersc.nmmu.ac.za

ISSN: 2221-4070

\title{
Making Wine Without Grapes: The Case for Quality Teaching With Limited Resources ${ }^{1}$
}

\author{
Jasmine Matope \\ ORCID No: 0000-0003-0818-8258 ID \\ IIE Varsity College Cape Town \\ 40794@iieconnect.co.za
}

\begin{abstract}
This article illustrates the significant role that creative, conscientious, dedicated, motivated, and committed teachers play in guiding, directing, and developing students' thinking, perspectives, and future lives. It highlights the importance of teacher agency in connecting learning to students' lives. It argues that good teachers can employ pedagogical practices that are not dependent on the availability of resources. It employs Pierre Bourdieu's theories of capital, field, and habitus to show how teachers can develop students' dispositions, consciousness, perceptions, perspectives, and lives. It also uses Nancy Fraser's theory of social justice to show how teachers can develop in working-class students, the essential knowledge, skills, and understandings that enable them to compete on a par with middle-class students. It uses life course theory to understand how the participants' schooling experiences, relationships, interconnectedness, and transitions influenced their thinking, doing, and lives. It employs a qualitative paradigm to explore five students' and one teacher's notions of how teaching and learning practices assisted the students to overcome the issue of inadequate resources. To locate the participants' perspectives and to analyse how their schooling experiences in the period 1968-1990 influenced their lives, the article uses the life history technique. The findings of the research stress that it is the inventiveness, competence, and attitude of the teacher that are the defining factors in the provision of quality education - not merely the availability of material resources.
\end{abstract}

Keywords: disadvantaged school, transformative agency, social justice, substantial knowledge, procedural knowledge

Copyright: (c) 2021 Matope

This is an open access article distributed under the terms of the Creative Commons Attribution NonCommercial License, which permits unrestricted non-commercial use, distribution, and reproduction in any medium, provided the original author and source are credited.

Please reference as: Matope, J. (2021). Making Wine Without Grapes: The Case for Quality Teaching With Limited Resources. Educational Research for Social Change, 10 (2), 33-46. http://dx.doi.org/10.17159/2221-4070/2021/v10i2a3

\footnotetext{
${ }^{1}$ Ethical clearance number: 20130605-12254
} 


\section{Introduction}

Literature highlights how a lack of adequate material resources impedes effective teaching and learning, giving rise to most underprivileged schools failing to produce competent students and good results (Khan \& Iqbal, 2012; Lacour \& Tissington, 2011; Sedibe, 2011). Elucidating the adverse effect of a lack of adequate teaching materials on teaching and learning, Sedibe (2011, p. 133) highlighted how "learners and teachers will lack opportunities to empower themselves and implement practical skills in any teaching and learning situation, thus hampering their critical and creative thinking." This article does concede that easy access to teaching materials and resources makes teaching and learning easier. However, considering the reality in most developing countries, and from personal experience, I contend that dedicated and imaginative teachers can effectively employ pedagogical strategies to develop students' critical thinking skills, reasoning, assertiveness, competency, agency, sense of selfworth, and responsible citizenry-irrespective of inadequate resources. It is in difficult circumstances that the great minds prove their ingenuity. This article hopes to add value to the debates on poor performance of students in disadvantaged schools as reported by various authors (Baker et al., 2017; Banerjee, 2016; Rammala, 2009; Shalem \& De Clercq, 2019; Sibanda, 2014), and to national and international debates on connecting students and their learning to life outside school (see, for example, Cloete, 2009; Sheppard \& Cloete, 2009). Given that there is little literature on, or evidence of, what makes good schools work-or on the cultures students are exposed to that allow them to go on and connect their learning to their future lives in productive ways - the article highlights what a reputable "previously disadvantaged" school under apartheid did to provide its students with the tools and understanding to engage with the social world after leaving school, and describes what the students say about what they took with them into life.

The motivation for this article originated from a concern that educationists tend to "blame" a lack of resources for the underperformance of students. Yet, I was intrigued by the performance of Victoria High School in the period 1968 to 1990, when education in South Africa was probably at its most repressive stage. Victoria High was one of the disadvantaged schools of that era, yet managed to provide educational spaces in which the students were able to develop their critical thinking capabilities and act as agents of personal change.

This article questions current debates on quality education in South Africa that suggest that good teaching happens only in former Model $\mathrm{C}$ schools. The discourses argue that these schools have adequate resources (infrastructure, playgrounds, textbooks, tablets, and a small teacher-to-pupil ratio), which promote high standards and meaningful learning (Lacour \& Tissington, 2011; Maserow \& Isaacs, 2015; Mitra et al., 2008; Sedibe, 2011). What these debates imply is that, when there are scanty resources, good teaching and learning do not take place. This preoccupation with resources and good teaching is not peculiar to South Africa; it is a global phenomenon (Khan \& Iqbal, 2012; Reardon, 2011). When most people talk about good education, they generally think of access to resources. Such perspectives suggest that, without adequate resources, teachers cannot promote the students' confidence, optimism, common sense, problem-solving skills, inventive thinking, and imagination.

I contend that ingenious teachers are capable of developing and broadening students' various skills and knowledge and their understanding of, and perspective on, the world-with or without adequate resources. Underscoring the primary role that creative teachers play in the learning and lives of students, Fafunwa (1969, pp. 36-37) noted that:

The demand for more and better schools, the need to relate curriculum to the needs of the child and the environment, the crying needs of the child and his other instructional materials, the desirability of training in vocational and technical skills, and indeed the 
overall problem of preparing the future citizens of Africa who will be fully oriented to their environment cannot be fully accomplished without the aid of competent teachers.

Indeed, a competent teacher has the capacity and will to work unwaveringly under any conditions to facilitate a positive change in the thinking and doing of students. I suggest that, when learning connects to individual dispositions and understandings, students develop the necessary tools to construct and navigate different pathways in the rest of their lives. Such learning provides them with mechanisms to exert their agency and transcend their social circumstance, as well as adopt different dispositions for subsequent challenges-highlighting how and what students are taught influences who they become. Malaguzzi (1998, p. 83) asserted that "learning and teaching should not stand on opposite banks and just watch the river flow by; instead, they should embark together on a journey down the water. Through an active, reciprocal exchange, teaching can strengthen learning how to learn."

To better understand the significance of pedagogical practices that connect learning to students' lives and develop students' agency, critical thinking, and reflexivity, I find Pierre Bourdieu, Nancy Fraser, and life course theories useful.

\section{Theoretical Framework}

I use Fraser's $(2007,2008)$ concept of social justice to understand how the greater representativity, access, and agency exercised at Victoria High School created and embedded tangible frameworks of social justice. I use the notions of recognition and redistribution to understand how one underresourced school, Victoria High School, in the period 1968 to 1990, engaged with statuses of difference-political, social, educational, and economic-and how the students sought to advance their positions under conditions of limited opportunity, poverty, poor schooling performance, early school leaving, severe economic deprivation, and social discontent (Ladd, 2012). Fraser's (2007) social justice theory suggested that the application of social justice to encourage parity in participation would overcome a variety of injustices and help dismantle institutionalised obstacles that prevent some people from participating "on par with others as full partners in social interaction" (Keddie, 2012, pp. $263-254)$.

I use the notion of social justice to demonstrate how redistribution does not only comprise economic capital, but also entails collective sharing of intellectual goods that deliver levels of critical thinking that allow students to operate in their new worlds in more equitable ways. I show how the notion of recognition is more than "equitable relationships" that foster understandings of the world and lead to more productive social interactions and mutual respect for different identities. Furthermore, the notion of recognition helps me to understand how, when students are not rejected and are encouraged to regard themselves as full human beings, they are able to compete effectively.

Bourdieu's concepts of habitus, capitals, and field are particularly important in providing means to understand the possibilities for schools and teachers to act in ways that improve the educational outcomes of marginalised students. Bourdieu's theories also offer useful and important ways to analyse the role and power of education in the lives of students, "linking pedagogy to social change, connecting critical learning to the experiences and histories that students bring to classrooms, and engaging the spaces of schooling as sites of contestation, resistance and possibility" (Giroux, 2003, p. $6)$.

The concept of capital assists me to understand past students' "ways of thinking and dispositions to life" that provided them with the "expected behaviours, expected language competencies, the explicit and implicit values, knowledge, attitudes to and relationship with academic culture required for 
success in school" (Henry et al., 1988, p. 233), despite access to inadequate resources. The notion of capital reveals how "accumulated labour," when "appropriated on a private basis by agents or groups of agents," enables students with the "appropriate social energy" to convert it into "forms of reified or living labour" (Bourdieu, 1986, p. 15).

Life course theory helps me to overcome the challenge of capturing both the conscious (what participants remembered) and unconscious (what participants chose not to remember or what they did not speak about) aspects of their personal narratives (Reissman, 1993). Life course theory importantly emphasises human agency in shaping life trajectories, the influence of socio-historical and geographical location, the relevance of past conditions or developments in informing present thinking, and the extent to which individual lives are linked and connected across time and space. This enables me to understand how cultural, political, economic, and social circumstances in the period 1968 to 1990 were tied to important human and historical developments and transitions that inevitably shaped the ways in which students experienced schooling under apartheid and how they thought about their futures.

These theories depict how teachers have the capacity to empower students with understanding, doing, and thinking to perform academic and social functions, as well as to adapt to changing circumstances. In this respect, Bourdieu (1971, p. 193) noted that "it may be assumed that every individual owes to the type of schooling he has received a set of basic, deeply interiorised master patterns." I now discuss the methodology I used to obtain information on students' perspectives on the quality teaching and learning at Victoria High School, which developed their knowledge and the skills they used in their transitions to life.

\section{Methodology}

I used a qualitative approach because I was dealing with past students' opinions on how Victoria High influenced their schooling and lives. In this regard, Cohen et al. (2001, p. 22) noted how such an enquiry is most appropriate for research on individuals or small groups if the objective is "to understand the subjective world of human experience and so to speak, to get inside the research participants' heads and understand from within." In utilising the qualitative paradigm, I followed a blended approach of life history and life course theory, described earlier, to gather data on the learning experiences of five participants who attended Victoria High in Cape Town as students in the period 1968 to 1990. The utilisation of a life history perspective was stimulated by Foucault's (1977) prompt that the challenge is not to think historically about the past but, rather, to use history to rethink the present. The life history approach helped me to obtain data from the participants on how the school framed their experiences, thinking, behaviour, and future lives in particular ways, and also to then locate this within their subsequent lives through their subjective gaze. In this respect, Wicks and Whiteford (2006) highlighted that:

Life stories are narratives used to reconstruct and interpret whole lives to obtain a comprehensive, over time, view of people's experiences. That is, they can be used to understand not only one life across time, but how individual lives interact with the whole. (p. 98)

Importantly, "comprehending some of the complexities, complications, and confusions within the life of just one member of a community" (Cole \& Knowles, 2001, p. 11) provided important ways to understand larger communities, how individuals are placed within those communities, and how meanings are made therein. 
To recruit participants, I contacted staff members and other people connected to the school who provided initial leads on past students who I then contacted. This rapidly spread into a web of contacts that I followed up, one by one. This network of relationships proved invaluable because different people provided different kinds of information on potential contacts and the school itself. This process was perhaps the most exciting part and probably yielded the richest data, overall (Ortner, 2003, p. 6). I used in-depth interviews as the most useful method to gather deep and detailed information from research participants. The interviews offered me ways to observe how the participants thought through and expressed their feelings about how the school connected learning to their lives, and to understand how they attached meaning to the way the teachers developed their agency, skills, and knowledge in particular ways. I held three interviews of roughly an hour each with each of the participants. To check the trustworthiness of the data, I read widely about the history of Victoria High, the kinds of students who attended the institution, some of the history of the areas in which the students lived, and the general history of Cape Town (political, social, economic, and educational between 1948 and 1990). Developing these prior insights was important to help facilitate interviews and also to triangulate and guide what was being said. To validate the students' responses, I interviewed one senior teacher who was also a former student at the school. I audiotaped and personally transcribed the interviews. I used a thematic approach to analyse the data. In Table 1, I display details of the participants' schooling years, pseudonyms, and their professions.

Table 1

Participants' Details

\begin{tabular}{llll}
\hline Participant & Years at Victoria High & Pseudonym & \multicolumn{1}{c}{ Eventual occupation } \\
\hline 1. & $1973-1977$ & Cheryl & Teacher \\
\hline 2. & $1976-1980$ & Ashley & Artist and designer \\
\hline 3. & $1977-1981$ & Noor & Lecturer \\
\hline 4. & $1978-1982$ & Meshack & Educational psychologist \\
\hline 5. & $1979-1983$ & Wallace & Cape Town city council \\
\hline 6. & 1960 s/1970s-1990s & Mr Walters & $\begin{array}{l}\text { Teacher (was a student at the school } \\
\text { in the 1960s/1970s and returned to } \\
\end{array}$ \\
& & & teach there in the 1990s) \\
\hline
\end{tabular}

I sought ethical clearance from my institution, and fieldwork approval from the Western Cape Education Department and district officials. I also sought permission from Victoria High School, although it appeared not to be necessary given that all the participants in the project had left the school more than 25 years previously. Nevertheless, I had envisioned visiting the school and using its documents.

\section{Discussion of Themes}

This section presents the two themes that emerged from interviews with the participants. I discuss how the school culture and teachers' pedagogical practices that connected learning to the students' contexts, and engagement with limited schooling resources influenced the students thinking, doing, and being.

\section{An Enabling Schooling Environment}

Davis and Jordan (1995, p. 570) noted that the culture and operation (culture and climate of school, classroom activities, kinds of curricula, teacher actions and instructional methods, and school-wide policies and standpoints) of the schools that students attend influence their learning and experiences in ways that have broader implications for their future educational attainment, employment, and 
family relations. The students who participated in the project commended Victoria High's school culture and their teachers for providing quality teaching with minimum resources. The teachers used various pedagogical strategies that challenged them to think differently about their situations, potential, and lives. This highlights how the quality of learning that students experience in school influences what they become when they exit school.

Cheryl outlined how the teachers effectively used pedagogical strategies that utilised every situation as an opportunity to learn. Illustrating how she benefited from the quality teaching, she noted:

There was a debating society. Especially in language classes, we had lots of debates and discussions. We invited speakers to come and address us and we would ask questions. I was part of the SRC [student representative council], and they provided opportunities for us within class time and outside of class time to discuss and to debate. In Grade 11 and 12, I had a German teacher. At first, I could not understand her methodology. After a while, I came to appreciate it because what she could do was teach us language through literature. That was brilliant, you know, she taught us sentence structure while you are busy reading your novel in German. What I also liked about her was her knowledge of German literature. She had an immense interest in the world, which she could share with us.

Reiterating the teachers' ingenuity, Cheryl highlighted that the teachers successfully encouraged students' extensive reading without a school library. The teachers "circulated the few books among the students and urged them to make use of the local municipality library." They guided them to select books that exposed them to quality, meaningful, relevant, and intellectually engaging materials and debates that stimulated their self-esteem, imagination, induction, reflection, critical thinking, world outlook, and contribution to society. This exposure, she asserted, empowered her to read between the lines, value teamwork, critically analyse work, and respect herself and others. These valuable skills became forms of capital that enabled her to successfully navigate her schooling. In this regard, Bourdieu (1987) highlighted how, when exposed to highbrow culture or middle-class habitus, workingclass children are capable of reasoning and thinking analytically and decisively.

Elucidating how the lack of resources was never considered a setback to all forms of teaching and learning, Cheryl outlined:

This may be funny, but I remember the school toilets, that's where I learnt to squat because we didn't have toilet pans/toilet seats. So, we would have very strong thighs because you had to sit like this [demonstrating]. The toilets were pathetic. We never had any toilet paper you had to take your own. The school grounds were small. We didn't have fancy soccer fields or stuff like that. Irrespective of this, we still did sport, excelled in sport, and loved sport.

Ashley corroborated the teachers' commitment to giving quality education. He explained how, even without a sports field and a school bus, the teachers promoted their extensive and successful participation in sport. He observed:

We had a teacher, Mr Willies, he had a car. We played rugby and rugby team has 15 guys. He took us with his car from the school to our venue. Take a group of boys and go back to take others. He was a white man and he never mourned about his petrol or time. We played till five, and he will drive each person to the nearest point. Also, our woodwork teacher, Mr Leonard told us every week to pay a R2 because of his passion for woodwork. 
Every week maybe 10 or 15 boys pay, and he saved for us. When the department would give us limited quantities of wood, he would put hands in his pocket and buy us extra wood for us to make big tables because the department would like us to make small tables. He did this because he knew the circumstances of the places we came from.

Echoing how the teachers' ingeniousness was not incapacitated by their lack of academic and sporting facilities, Wallace explained:

Victoria High is not a school known for facilities. For many years, the school has used a row of stables, which they converted into classrooms. So, Victoria High never had good facilities. It didn't have a swimming pool, didn't have a big sport field, and didn't have a hall, a fully equipped gymnasium. We went to Victoria High because it was known, and I believe even today is still known for a good standard of education. Parents didn't send their children to get better facilities at the school. They sent them to get good tuition.

Cheryl, Ashley, and Wallace attributed their success and great accomplishments to the teachers' diligence, commitment, and aplomb. They were encouraged to be optimistic and constantly reminded that their capacity to perform could not be hindered by the school's lack of material resources. Although the school had no sporting fields and equipment, this was never regarded as an excuse to deprive the students of fully engaging in sport. The teachers thought on their feet and sought permission to use the local municipality swimming pool and sport grounds for several sporting disciplines. At times, they only had to access some facilities after school hours or over the weekend but this was gladly accepted. These students' narratives challenge some authors (for example, Jeroh, 2012; Mchunu, 2008) who contended that sport cannot be performed successfully if there are shortages in the amount and kinds of equipment and sporting facilities. The teachers at Victoria High School thought outside the box and improvised to overcome their conundrum. In this respect, LadsonBillings (1994) considered imaginative teachers to be capable of successfully incorporating texts and pedagogical strategies that are culturally and linguistically responsive in order to increase students' efficacy, motivation, and academic achievement.

Wallace further outlined that many children travelled long distances because they wanted to get the good education that was offered at Victoria High School: "Even some of the children from wealthy families came to the school because the quality of the education surpassed some of the well-resourced schools by that time." According to Wallace, the teachers provided students with competitive learning skills and knowledge, notwithstanding the inadequate resources:

Victoria High didn't charge high fees and I believe, even today, its fees are very low. My daughter goes to an ex-Model C school in Newlands, a lovely school. We couldn't go there when we were children as it was for whites only. The school has fantastic facilities. They have intelligent white boards that you can write on, massive swimming pools, tennis courts, cricket fields, massive fields, halls where you can have these fancy auditoriums, but Victoria High never used to have these in the 1980s. We had no hall and when it was raining, we would open the doors that separated two classrooms and we would stand there for the assemblies, but what we learnt at assemblies was fabulous, high intellectual stuff.

Wallace further outlined that the high quality of learning provided at the school, despite the limited resources, lured many students to the school from both near and far. He explained: 
A lot of children came from township-Khayelitsha, Nyanga, Langa, Habibia, Mitchell's Plain, Strandfontein and Manenberg - to Victoria High in search of good education at a cheap price. Even parents who could afford to send their children to better resourced schools sent them to Victoria high because it was highly competitive.

This translocation of students to a poorly resourced school to get good education depicts how poor schools can develop positive dispositions in students, which raise their individual expectations and agency, and their ability to overcome their social class disadvantages. In this regard, Bourdieu (1990, p. 82) highlighted how teachers can assist working-class students to adopt middle-class habitus, deportment, preferences, and expectations that mark out their various social positions. This develops the students' "creative, active, inventive capacity" (Bourdieu, 1990, p. 13) to overcome their poor social class background and limiting circumstances.

Also demonstrating how the academic reputation of the school attracted students, Noor noted:

\begin{abstract}
I heard other students from other schools saying Victoria High was sort of a bourgeoisie school because everybody wanted to attend Victoria High and there was always a long waiting list of over 100 students who wanted to come-come to Victoria High, but then the school was full. I tell you if you were to come to Victoria High 1977 to 1981, the school was full. We used to be about 40 or 50 in a class. We sat in the prefabs, which were either very, very hot or very, very cold. Windows were broken but everyone wanted to be at Victoria High, you see. We sat in prefabricated classrooms, which were temporary classrooms; but we sat there because we wanted to be educated so you would not mind sitting in a Victoria High classroom with 40 or 50 students/learners or go to another school with fewer learners. We always had the ideas that they might not give you the same academic lessons we got.
\end{abstract}

Noor further explained that, although classes were overcrowded, they did not experience congestion as a hindrance to learning because there were no cases of indiscipline, disengagement, or unwarranted absenteeism because the teachers were passionate about their jobs and demonstrated their high knowledge and skills. He outlined that, although the teachers had no fancy teaching resources or wellresourced staffroom with computers, they were widely read and very critical. They created a supportive and caring classroom atmosphere that stirred the students' confidence and zeal for lifelong learning and gave them an understanding of their various subject contents. Noor attested that extensive reading and critical thinking became core features of the teaching and learning at the school.

Reiterating the teachers' efficacy, he said:

The teachers never complained that we do not have facilities; they realised that it is the effort, the work that matters more than the facilities, that's why you look at Victoria High today it is a school to be proud of. Not just mourn over resources like most schools do today. The teachers and the parents were committed to keep the flag of the school flying.

Noor further explained that what made the students successful were not resources, but their knowledgeable and diligent teachers who were committed to making a difference in the students' lives. In this respect, Bourdieu (1986) said that teachers can possess strong knowledge of the codes of power that give them a clear understanding of the value systems and discourse patterns prevalent in the educational system, which they can use to promote the academic success of students. Thus, teachers can assist working-class students to gain access to the codes, or rules, of the middle class and enable them to participate confidently in their schoolwork and lives. 
Similarly, Meshack highlighted how the dedicated teachers were not daunted by inadequate material resources and remained resolute and visionary in doing their utmost to promote the intellectual and social development of the students:

When we were at Victoria High School, we would not talk about resources. We learnt in the prefabs, very cold in winter. We had another block of bricks towards the back of the stables. As a school, there was more to it than resources. We didn't have a hall or sporting fields. We were a disadvantaged school, and the teachers had a calling for the job and not money.

Meshack accentuated how the commitment, devotion, passion, critical thinking, inspiration, and guidance of the teachers at Victoria High School promoted the students' agency, optimism, and enthusiasm to make a difference in their lives. They were empowered to challenge their limitations intellectually. Their audacity and proficiency to occupy different key positions of leadership and authority were promoted. Elaborating on the school's focus on achievement, despite not having sufficient material resources, Meshack explained:

Most of our present political leaders came from Victoria High. There is a guy who went with me to school and is a chief executive of one of the big companies in the country. Quite a number of ministers with key positions in the government came from Victoria High School.

The students ascribed their profound success not only to the discourses that prevailed but, more importantly, to the pedagogical practices of the teachers, as outlined in the following section.

\section{Teaching With Limited Resources}

Mr Walters, a teacher and former student at Victoria High School, said that when he was recruited to teach at the school, he received induction sessions that encouraged him to rack his brains. He was inspired to be diligent, erudite, a lifelong learner, to work in teams and, most importantly, to be a good role model to the students. Explaining the school's position and stance on its lack of resources, $\mathrm{Mr}$ Walters noted:

What made the school overcome the insufficient resources about which most schools complain, was the fact that the school considered the teachers as great assets with the ability to transform the students' schooling conditions and future lives.

$\mathrm{Mr}$ Walters further highlighted that the school management regarded the role of the teacher as prime in the students' learning and encouraged all teachers to be subject pundits who employed appropriate teaching methods. This, he asserted, empowered the teachers to do their best with the limited material resources at their disposal. Elucidating how the school overcame the issue of resources, $\mathrm{Mr}$ Walters said:

Victoria High School never complained about the lack of resources because the teachers were encouraged (by the school management) to be widely read and knowledgeable. Most of the teachers were studying through University of South Africa. Myself, I started with the basic teacher's certificate, but I had to study to perform better. That was the kind of resource. You can't be a source of motivation if you have nothing within you. You have to develop yourself, to be that resource and, as teachers, we were studying; some through formal studies and others through mere discussion groups among the teachers-with 
other schools, among ourselves, we had discussion groups. This was the message that was then disseminated to the students, and it motivated them to work hard.

Mr Walters' view of the importance of teachers studying further resonates with the assertion by Rabindranath Tagore, who won the Nobel Prize in literature in 1913:

\begin{abstract}
A teacher can never truly teach unless he is still learning himself. A lamp can never light another lamp unless it continues to burn its own flame. The teacher who has come to the end of his subject, who has no living traffic with his knowledge but merely repeats his lesson to his students, can only load their minds, he cannot quicken them. (as quoted in Dutta \& Robinson, 1997, p. 66)
\end{abstract}

Further outlining how the teachers were urged to be authorities on their subject content, Mr Walters noted:

We had lots of arguments and debates and I think these were important at the time. For example, when the University of the Western Cape [UWC] was opened, there was a debate because the first intention of that university was to serve a particular group of people. It was a coloured university and there was a heavy debate as to whether we should boycott that because it was giving credence to the intentions of the state. And that was a heavy argument, heavy debate, which you know, we ultimately had to say there were alternatives, because you needed to have a subject not offered at the UWC to get to Cape Town University. Say a student had to do an odd subject like architecture, a subject not offered at UWC to get to Cape Town University. So that was a major debate which caused lots of tensions and discussions among the staff, but in the light of where else to go to, many including myself conceded that they must go there. Do what you have to do; under protest, get your qualification and get out. Some decided we will go there, and we will not graduate at the graduation ceremony, so there were a lot of tensions around that and you will understand these difficult decisions.

Mr Walters reiterated that the national and international debates not only connected the students and their learning to life outside school, but developed critical thinking, problem-solving skills, and identity in key ways. He highlighted assertively that the teachers were instrumental in nurturing the students' problem-solving skills and yearning to learn. Besides the debates, they used discussions, group interaction, peer teaching, sporting activities, and social welfare (civic) clubs to empower the students to participate actively and take responsibility for their learning:

One of the debates at that time was whether South Africa should be called Azania. It was a fierce debate. Some highlighting why it had to be called Azania and others why it should not be called Azania.

Importantly, such vigorous debates encouraged the students to imagine and think deeply and analytically about what was happening around them and how their decisions and choices would influence the kinds of future lives they were to lead. The debates empowered the students to embrace challenges on an informed level.

Mr Walters further asserted that passionate teachers can always make a difference to the learning and lives of students using minimum resources. Substantiating the greater role that teachers played in teaching, Mr Walters recounted his working experience with the national department of education, noting: 
There was excellent teaching and learning in some mud schools in the Eastern Cape. The schools had barely the basics; even in the mud schools of the Eastern Cape, you can get excellence. So, what is it that makes a teacher in a mud school in the Eastern Cape get children to read better than urban children? No resources, no Wi-Fi phones, no electronic tablets, and what not. I believe that if you have a dedicated, competent teacher, it's your greatest asset. You can have your white board and I have seen it, white boards and all that, those things only work well with good teachers. In the hands of poor teachers, they are useless.

Mr Walters argued that the teachers were the mobile resources who were tirelessly ready to direct and guide the students' learning. Significantly, while Fraser $(2007,2008)$ suggested that teachers should redistribute economic resources to marginalised students to help them compete on a par with well-resourced schools, Mr Walters highlighted that the teachers at Victoria High School redistributed knowledge and skills to the students that developed their self-esteem, confidence, and agency, thereby enabling them to work hard and overcome the constraints posed by the limiting resources. The teachers created spaces that developed the students' capacities to participate in equitable ways as full members of society-which Nancy Fraser termed participatory parity and which is the goal of social justice.

\section{Implications for Teacher Development}

Mr Walters said:

Teachers are the tremendous resource for children, not only in terms of knowledge, but motivation as well. I believe that resources are important, make no mistake, they are important, but they are only beneficial in the hands of a good teacher. In the hands of a poor teacher, they are useless, because there is no resource that can take over the role of a teacher.

Mr Walters' narrative depicts that the greatest resource in a teaching and learning environment is the teacher. As stated earlier by Tagore (in Dutta \& Robinson, 1997, p. 66), "a teacher can never truly teach unless he is still learning himself," therefore there is need to continually develop teachers. This would improve and maintain their intellectual and social capitals, as advocated by Bourdieu, to be able to develop their students' agency. Therefore, in teacher development and training programmes, the teachers should be equipped to be highly innovative to the extent that they can convey their lessons effectively even with limited resources. In other words, the teachers should become highly intuitive, ingenious, and creative in their teaching and learning such that lack of resources would be a minor issue.

The government, non-governmental organisations, and school governing bodies should provide workshops and training sessions that help teachers to share their methods of quality teaching with limited resources. At governmental level, the teachers might also be provided with research grants and study leave to allow them to advance their qualifications, for example, those with diplomas could obtain degrees in their teaching areas. At school governmental level, teachers could be afforded subject enrichment courses in which they engaged with their school contexts and in productive discussions to share constructive ideas and teaching strategies to enhance quality teaching and learning, even with limited resources. When teachers are encouraged to keep their intellectual batteries charged, they become motivated and can innovatively employ pedagogical strategies that meaningfully promote students' participation, critical thinking, autonomy, flexibility, responsibility, and agency. 


\section{Conclusion}

The narratives of the participants highlight that teachers are the greatest resource in teaching and learning. Pierre Bourdieu's theories of capital, field, and habitus enabled understanding of the significant role of teachers in developing students' language codes, behaviours, consciousness, perceptions, perspectives, and lives. Nancy Fraser's theory of social justice showed how teachers can develop in working-class students, essential knowledge, skills, and understandings to enable them to overcome their disadvantages. The themes outline how motivated, committed, diligent, and innovative teachers are capable of using effective pedagogical strategies and engaging with the curricula in ways that promote social norms, skills, knowledge, attitudes, and behaviours that make students' learning meaningful and interesting despite limited resources. The article argues that ingenious teachers connect teaching and learning to the students, and promote the students' dispositions, enthusiasm, optimism, confidence, courage, respect, responsibility, agency, citizenry, problem solving and critical thinking, and acquisitions of necessary tools to use to construct their schooling, transitions, and life pathways. Given that teachers are the greatest resource in the teaching and learning environment, it is essential that they constantly engage in staff development sessions to enhance their substantive subject knowledge and effective pedagogical strategies to deliver quality teaching even with limited resources.

\section{Acknowledgements}

This article is drawn from my doctoral thesis (Matope, 2016), and I would like to acknowledge the supervisors of the thesis: Professor Aslam Fataar, Stellenbosch University and Professor Azeem Badroodien, Cape Town University.

\section{References}

Baker, D., LeTendre, G., \& Goesling, B. (2017). Rich land, poor schools: Inequality of national educational resources and achievement of disadvantaged students. In A. R. Sadovnik, P. W., Cookson, S. F., Semel, \& R. W. Coughlan (Eds.), Exploring education: An introduction to the foundations of education (pp. 248-257). Routledge. https://doi.org/10.4324/9781315408545

Banerjee, P. A. (2016). A systematic review of factors linked to poor academic performance of disadvantaged students in science and maths in schools. Cogent Education, 3(1), 1-17. https://doi.org/10.1080/2331186X.2016.1178441

Bourdieu, P. (1971). Systems of education and systems of thought. In M. F. D. Young (Ed.), Knowledge and control: New directions for the sociology of education (pp. 189-207). Collier-Macmillan.

Bourdieu, P. (1986). The forms of capital. In J. G. Richardson (Ed.), Handbook of theory and research for the sociology of education (pp. 241-258). Greenwood Press.

Bourdieu, P. (1987). What makes a social class? On the theoretical and practical existence of groups. Berkley Journal of Sociology, 32, 1-8. https://www.jstor.org/stable/41035356

Bourdieu, P. (1990). The logic of practice. Stanford University Press.

Cloete, N. (Ed.). (2009). Responding to the educational needs of post-school youth: Determining the scope of the problem and developing a capacity-building model. Centre for Higher Education Transformation.

Cohen, L., Manion, L., \& Morrison, K. (2001). Research methods in education. Routledge. https://doi.org/10.4324/9781315456539

Cole, A. L., \& Knowles, J. G. (2001). Lives in context: The art of life history research. AltaMira 
Davis, J. E., \& Jordan, W. J. (1995). The effects of school context, structure, and experiences on African American males in middle and high schools. Journal of Negro Education, 63(4), 570-587. https://doi.org/10.2307/2967296

Dutta, K., \& Robinson, A. (1997). Rabindranath Tagore: The myriad-minded man. Bloomsbury.

Fafunwa, B. (1969). The purpose of teacher education. In A. Adaralegbe (Ed.), A philosophy for Nigerian education: Proceedings of the Nigerian National Curriculum Conference (pp. 36-37). Nigeria Educational Research Council.

Foucault, M. (1977). Discipline and punish: The birth of the prison. Vintage.

Fraser, N. (2007). Re-framing justice in a globalizing world. In N. Fraser \& P. Bourdieu (Eds.), (Mis)recognition, social inequality, and social justice (pp. 17-35). Routledge.

Fraser, N. (2008). Reframing justice in a globalizing world. In K. Olson (Ed.), Adding insult to injury: Nancy Fraser debates her critics (pp. 273-291). Verso.

Giroux, H. A. (2003). Public pedagogy and the politics of resistance: Notes on a critical theory of educational struggle. Educational Philosophy and Theory, 35(1), 5-16. https://doi.org/10.1111/1469-5812.00002

Henry, M., Knight, J., Lingard, R., \& Taylor, S. (1988). Understanding schooling: An introductory sociology of Australian education. Routledge.

Jeroh, E. J. (2012). Standard sports facilities as predictor for elite sports performance by Nigerian university students. Journal of Physical Education and Sport, 12(1), 44-47. https://efsupit.ro/images/stories/nr\%201\%202012/vol\%2012 $1 \% 20$ art\%208.pdf

Keddie, A. (2012). Schooling and social justice through the lenses of Nancy Fraser. Critical Studies in Education, 53(3), 263-279. https://doi.org/10.1080/17508487.2012.709185

Khan, P., \& Iqbal, M. (2012). Overcrowded classroom: A serious problem for teachers. Elixir Educational Technology, 49, 10162-10165. https://www.elixirpublishers.com/articles/1351260412 49\%20(2012)\%2010162-10165.pdf

Lacour, M., \& Tissington, L. D. (2011). The effects of poverty on academic achievement. Educational Research and Reviews, 6(7), 522-527. https://academicjournals.org/article/article1379765941 Lacour\%20and\%20Tissington.pdf

Ladd, H. F. (2012). Education and poverty: Confronting the evidence. Journal of Policy Analysis and Management, 31(2), 203-227. https://doi.org/10.1002/pam.21615

Ladson-Billings, G. (1994). The dreamkeepers: Successful teachers of African American children. JosseyBass.

Malaguzzi, L. (1998). History, ideas and philosophy. In C. Edwards, L. Gandini, \& G. Forman (Eds.), The hundred languages of children (pp. 83-100). Greenwood.

Maserow, J., \& Isaacs, D. (2015). Taking equal education into the classroom: The challenges to teaching and learning, and possible campaigns to address the crisis of quality and equality in the pedagogic encounter. Equal Education.

Matope, J. (2016). Discourses of learning, transition and agency amongst students who attended a Cape Town high school under apartheid [Doctoral thesis, University of Stellenbosch]. SUNScholar Research Repository. https://scholar.sun.ac.za/handle/10019.1/100051

Mchunu, S. J. A. (2008). Reasons for nonparticipation in sport by black learners at secondary school level [Master's thesis, University of South Africa]. http://uir.unisa.ac.za/bitstream/handle/10500/649/dissertation. pdf;isessionid=2276EB8553F02F 589839AE5F035C6D54?sequence $=1$ 
Mitra, S., Dangwa, R., \& Thadani, L. (2008). Effects of remoteness on the quality of education: A case study from North Indian schools. Australasian Journal of Educational, 24(2), 168-180. https://doi.org/10.14742/AJET.1219

Ortner, S. B. (2003). New Jersey dreaming: Capital, culture, and the class of '58. Duke University Press.

Rammala, M. S. (2009). Factors contributing towards poor performance of Grade 12 learners at Manoshi and Mokwatedi high schools [Master's thesis, Turfloop Graduate School of Leadership, University of Limpopo]. http://ulspace.ul.ac.za/bitstream/handle/10386/224/M.S\%20RAMMALA\%20\%289434028\%29.pd f?sequence $=1 \&$ isAllowed $=y$

Reardon, S. F. (2011). The widening academic achievement gap between the rich and the poor: New evidence and possible explanations. In R. Murnane \& G. Duncan (Eds.), Whither opportunity? Rising inequality and the uncertain life chances of low-income children (pp. 91-117)). Russell Sage Foundation Press.

Reissman, C. (1993). Narrative analysis. SAGE.

Sedibe, M. (2011). Inequality of access to resources in previously disadvantaged South African high schools. Social Science, 28(2), 129-135. https://doi.org/10.1080/09718923.2011.11892937

Shalem, Y., \& De Clercq, F. (2019). Teacher development and inequality in schools: Do we now have a theory of change? In N. Spaull \& J. D. Jansen (Eds.), South African schooling: The enigma of inequality a study of the present situation and future possibilities (pp. 243-261). Springer.

Sheppard, M., \& Cloete, N. (2009). Scoping the need for post -school education. In N. Cloete (Ed.), Responding to the educational needs of post-school youth: Determining the scope of the problem and developing a capacity-building model (pp.19-44). Centre for Higher Education Transformation.

Sibanda, I. (2014). An investigation into the factors associated with high school learners' poor performance in Physical Science in the Libode District in the Eastern Cape [Master's thesis, University of South Africa]. https://core.ac.uk/download/pdf/83637597.pdf

Wicks, A., \& Whiteford, G. (2006). Conceptual and practical issues in qualitative research: Reflections a life history study. Scandinavian Journal of Occupational Therapy, 13(2), 94-100. https://doi.org/10.1080/11038120600654676 